\title{
Front Matter: Volume 7707
}

, "Front Matter: Volume 7707," Proc. SPIE 7707, Defense Transformation and Net-Centric Systems 2010, 770701 (13 May 2010); doi: 10.1117/12.866987

SPIE Event: SPIE Defense, Security, and Sensing, 2010, Orlando, Florida, United SPIE. States 


\section{PROCEEDINGS OF SPIE}

\section{Defense Transformation and Net-Centric Systems 2010}

Raja Suresh

Editor

6-8 April 2010

Orlando, Florida, United States

Sponsored and Published by

SPIE 
The papers included in this volume were part of the technical conference cited on the cover and title page. Papers were selected and subject to review by the editors and conference program committee. Some conference presentations may not be available for publication. The papers published in these proceedings reflect the work and thoughts of the authors and are published herein as submitted. The publisher is not responsible for the validity of the information or for any outcomes resulting from reliance thereon.

Please use the following format to cite material from this book:

Author(s), "Title of Paper," in Defense Transformation and Net-Centric Systems 2010, edited by Raja Suresh, Proceedings of SPIE Vol. 7707 (SPIE, Bellingham, WA, 2010) Article CID Number.

ISSN 0277-786X

ISBN 9780819481719

Published by

SPIE

P.O. Box 10, Bellingham, Washington 98227-0010 USA

Telephone +1 3606763290 (Pacific Time) · Fax +1 3606471445

SPIE.org

Copyright (c) 2010, Society of Photo-Optical Instrumentation Engineers

Copying of material in this book for internal or personal use, or for the internal or personal use of specific clients, beyond the fair use provisions granted by the U.S. Copyright Law is authorized by SPIE subject to payment of copying fees. The Transactional Reporting Service base fee for this volume is $\$ 18.00$ per article (or portion thereof), which should be paid directly to the Copyright Clearance Center (CCC), 222 Rosewood Drive, Danvers, MA 01923. Payment may also be made electronically through CCC Online at copyright.com. Other copying for republication, resale, advertising or promotion, or any form of systematic or multiple reproduction of any material in this book is prohibited except with permission in writing from the publisher. The CCC fee code is 0277-786X/10/\$18.00.

Printed in the United States of America.

Publication of record for individual papers is online in the SPIE Digital Library.

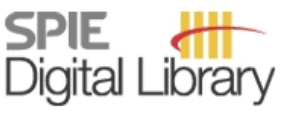

SPIEDigitalLibrary.org

Paper Numbering: Proceedings of SPIE follow an e-First publication model, with papers published first online and then in print and on CD-ROM. Papers are published as they are submitted and meet publication criteria. A unique, consistent, permanent citation identifier (CID) number is assigned to each article at the time of the first publication. Utilization of CIDs allows articles to be fully citable as soon they are published online, and connects the same identifier to all online, print, and electronic versions of the publication. SPIE uses a six-digit CID article numbering system in which:

- The first four digits correspond to the SPIE volume number.

- The last two digits indicate publication order within the volume using a Base 36 numbering system employing both numerals and letters. These two-number sets start with 00, 01, 02, 03, 04 , $05,06,07,08,09,0 A, 0 B \ldots$. OZ, followed by 10-1Z, 20-2Z, etc.

The CID number appears on each page of the manuscript. The complete citation is used on the first page, and an abbreviated version on subsequent pages. Numbers in the index correspond to the last two digits of the six-digit CID number. 


\title{
Contents
}

\author{
$\checkmark$ Conference Committee \\ vii Introduction
}

SELF-ORGANIZING, COLLABORATIVE, AND UNMANNED ISR ROBOTS: JOINT SESSION WITH CONFERENCE 7692

770703 Fuel cell systems for long duration electric UAVs and UGVs [7707-04]

J. Baldic, P. Osenar, N. Lauder, P. Launie, Protonex Technology Corp. (United States)

770704 Whole-body task energy metrics for robots performing useful work in unstructured environments [7707-05]

A. Hofmann, D. Theobald, Vecna Technologies, Inc. (United States)

\section{COMMUNICATION NETWORKS AND DYNAMIC SPECTRUM ACCESS}

770705 Software defined radio based multi-carrier multi-function waveform for cognitive radio (Invited Paper) [7707-06]

R. Zhou, X. Li, Wright State Univ. (United States); V. Chakravarthy, Air Force Research Lab. (United States); Z. Wu, Wright State Univ. (United States)

770706 Efficacy of compressive sensing for dynamic spectrum access [7707-07]

O. Odejide, A. Annamalai, C. Akujuobi, Prairie View A\&M Univ. (United States)

770707 Wideband signal detection using a Nyquist folding analog-to-information receiver in multipath fading environments [7707-08]

O. Odejide, A. Annamalai, C. Akujuobi, Prairie View A\&M Univ. (United States)

770708 Congestion game model for efficient utilization of spectrum [7707-09]

Y. B. Reddy, H. Smith, Grambling State Univ. (United States)

770709 A fuzzy logic approach to cross-layer route optimization in multi-hop CRNs [7707-10] R. Murawski, E. Ekici, The Ohio State Univ. (United States); R. W. Thomas, Air Force Institute of Technology (United States)

7707 OB Multiple UAV tomography based geolocation of RF emitters [7707-12]

D. Walter, J. Klein, J. Kaupert, Rose-Hulman Institute of Technology (United States);

C. Bullmaster, V. Chakravarthy, Wright Patterson Air Force Base (United States)

7707 OC Dynamic spectrum access in wireless ad hoc networks: issues and possible solutions [7707-13]

Z. Zhang, T. Soni, Argon ST, Inc. (United States)

7707 OD Quality of service for tactical wireless networks [7707-14]

R. Ordower, N. Newman, J. Myrtle, SAIC (United States) 
7707 OE Distributed game-theoretic topology control in cognitive networks [7707-15]

E. van den Berg, M. A. Fecko, S. Samtani, C. Lacatus, Telcordia Technologies, Inc. (United States); M. Patel, U.S. Army CERDEC (United States)

\section{NET-CENTRIC ARCHITECTURES AND INFORMATION ASSURANCE}

7707 OG Building net-centric data strategies in support of a transformational MIW capability (Invited Paper) [7707-17]

M. A. Cramer, Mine Warfare Program Office (United States); J. Stack, Office of Naval Research (United States)

$7707 \mathrm{OH} \quad$ Locative view: visualizing geo-referenced objects in space [7707-18] M. Carlotto, M. Nebrich, P. Hylton, General Dynamics Advanced Information Systems (United States)

7707 Ol System approach to distributed sensor management [7707-19] G. Mayott, U.S. Army Night Vision \& Electronic Sensors Directorate (United States); G. Miller, J. Harrell, J. Hepp, Oakwood Controls, Corp. (United States); M. Self, CACI Technologies, Inc. (United States)

7707 OK Resource brokering service: timely and efficient information resource allocation [7707-21] D. J. Van Hook, M. Ljungberg, R. Shaw, M. Ford, E. Aubin, MIT Lincoln Lab. (United States); E. Konieczny, D. H. Lee, S. T. Brown, Booz Allen Hamilton (United States)

7707 OM Security core to the edge: securing critical information through enhanced Cross Domain Systems (CDS) to the tactical edge [7707-23]

B. S. Farroha, TASC, Inc. (United States); D. L. Farroha, M. M. Whitfield, U.S. Dept. of Defense (United States)

7707 ON Metrics for measuring net-centric data strategy implementation [7707-24]

J. B. Kroculick, Winifred Associates (United States)

770700 Enterprise systems security management: a framework for breakthrough protection [7707-26]

B. S. Farroha, TASC, Inc. (United States); D. L. Farroha, U.S. Dept. of Defense (United States)

SENSOR NETWORKS AND COMMUNICATIONS I: JOINT SESSION WITH CONFERENCE 7694

$77070 Q \quad$ Co-evaluation computation-based distributed intrusion detection system [7707-28]

J. Su, P. Qiao, T. Li, Harbin Univ. of Science and Technology (China)

Author Index 


\title{
Conference Committee
}

\author{
Symposium Chair
}

Michael T. Eismann, Air Force Research Laboratory (United States)

Symposium Cochair

William Jeffrey, HRL Laboratories, LLC (United States)

Conference Chair

Raja Suresh, General Dynamics Advanced Information Systems (United States)

Program Committee

Keith Arthur, U.S. Army Aviation Applied Technology Directorate (United States)

Vasu D. Chakravarthy, Air Force Research Laboratory (United States)

Melanie Dumas, Defense Advanced Research Projects Agency (United States)

John S. Eicke, Army Research Laboratory (United States)

Paul Gaertner, Defence Science and Technology Organisation (Australia)

Gayle D. Grant, U.S. Army Communications-Electronics Command

(United States)

Robert G. Hillman, Air Force Research Laboratory (United States)

Michael A. Kolodny, Army Research Laboratory (United States)

Leo J. Rose, Air Force Research Laboratory (United States)

Larry B. Stotts, Defense Advanced Research Projects Agency (United States)

Venkataraman Sundareswaran, Teledyne Scientific Company (United States)

Guy Vézina, Defence Research and Development Canada, Valcartier (Canada)

Session Chairs

1 Self-Organizing, Collaborative, and Unmanned ISR Robots: Joint Session with Conference 7692

Grant R. Gerhart, U.S. Army Tank-Automotive Research, Development and Engineering Center (United States)

Melanie Dumas, Defense Advanced Research Projects Agency (United States) 
2 Communication Networks and Dynamic Spectrum Access

Vasu D. Chakravarthy, Air Force Research Laboratory (United States) Gayle D. Grant, U.S. Army Communications-Electronics Command (United States)

3 Net-Centric Architectures and Information Assurance

Paul Gaertner, Defence Science and Technology Organisation

(Australia)

Leo J. Rose, Air Force Research Laboratory (United States)

4 Sensor Networks and Communications I: Joint Session with Conference 7694

Michael A. Kolodny, U.S. Army Research Laboratory (United States)

5 Sensor Networks and Communications II: Joint Session with Conference 7694

Michael A. Kolodny, U.S. Army Research Laboratory (United States) 


\section{Introduction}

These are the proceedings of the fifteenth Defense Transformation and Netcentric Systems conference. The papers presented at the conference strongly reflected the inexorable trend towards net-centric systems and service oriented architectures. The conference included the following special sessions:

- Self-organizing, Collaborative, and Unmanned ISR Robots, held jointly with the Unmanned Systems Technology conference $\mathbf{7 6 9 2}$

Collaborative autonomous systems portend the increasing use of autonomic sensor and shooter platforms to perform the D3 (Dirty, Dull, and Dangerous) missions in an era of declining force structures.

- Communication Networks and Dynamic Spectrum Access

This is an important topic which was initially pioneered by DARPA and highlighted as a key need by the Air Force Scientific Advisory Board in a 2008 summer study.

- Sensor Networks and Communications, held jointly with the Ground/Air Multi-sensor Interoperability, Integration, and Networking for Persistent ISR conference 7694

The conference also included a presentation by invited speaker Mr. Jim Springer of the U.S. Army on the UAS Control Segment (UCS) initiative, which detailed intentions to bring about an Open Architecture Ground Segment for UAS, and igniting a drive away from stove-piped proprietary systems.

Looking ahead, we expect Net-centric systems to be increasingly deployed in the field as C4ISR systems undergo their own "revolution". In the future, we expect to focus on the networking of sensors and shooters from space to the mud, as well as distributed collaborative teams of robotic platforms.

It is gratifying to see the high level of audience interest in this conference. Particularly gratifying is the fact that this conference has resulted in the "spin-off" of two new conferences at SPIE. My sincere thanks to the distinguished invited speakers, authors, attendees, and my associates on the program committee for another successful conference.

Raja Suresh 
Downloaded From: https://www.spiedigitallibrary.org/conference-proceedings-of-spie on 26 Apr 2023

Terms of Use: https://www.spiedigitallibrary.org/terms-of-use 